OPEN ACCESS

Vol. 7, No. 2, Oktober, 2019

Page. $44-96$

DOI: https://doi.org/10.21107/jaffa.v7i2.6421
JOURNAL OF AUDITING, FINANCE, AND FORENSIC ACCOUNTING (JAFFA)

E-ISSN: 2461-0607 ISSN: 2339-2886

https://journal.trunojoyo.ac.id/jaffa/index

\title{
FORENSIC ACCOUNTING AND INTELLIGENCE GATHERING APPROACHES ON THE MANAGEMENT OF TERRORIST FINANCING IN NIGERIA
}

Aruwaji Akinola Mkchael, Olatunji Toyin Emmanuel

Ladoke Akintola University of Technology, Ogbomosho, Oyo State, Nigeria

\section{Article Info:}

Received: 27 July 2019

in revised form: 1 October 2019

Accepted: 18 November 2019

Available Online: 13 Januari 2020

\section{Keywords:}

Forensic accounting, intelligence gathering, factor analysis, terrorist financing

Corresponding Author:

Email: macfarade@gmail.com
Abstract; The management of terrorism financing involves the ability to achieve control over the source, cash flow and destination of terrorists. This study examined the effects of forensic accounting and the radians of intelligence gathering approaches in the investigation of terrorist financing in Nigeria. The data for this study were sourced through primary and secondary sources. Econometrics (Factor analysis with PCA and Pearson Correlation) were used for the analyses at 0.05 level of significant. The results purview that forensic accounting approaches and intelligence gathering tool are significant in investigating the source, pathway, destination and the utilization of the resources of terrorists. It was concluded that Nigeria government should establish response to terrorism/ terror financing under the presidency to manage the problem of terror financing.

Abstrak; Manajemen pendanaan terorisme melibatkan kemampuan untuk mencapai kontrol atas sumber, arus kas, dan tujuan teroris. Studi ini meneliti efek akuntansi forensik dan radian dari pendekatan pengumpulan intelijen dalam penyelidikan pendanaan teroris di Nigeria. Data untuk penelitian ini bersumber dari sumber primer dan sekunder. Ekonometrik (Analisis faktor dengan PCA dan Pearson Correlation) digunakan untuk analisis pada tingkat signifikansi 0,05. Hasil penelitian menyatakan bahwa pendekatan akuntansi forensik dan alat pengumpulan intelijen sangat penting dalam menyelidiki sumber, jalur, tujuan dan pemanfaatan sumber daya teroris. Disimpulkan bahwa pemerintah Nigeria harus menanggapi terorisme/pendanaan teror di bawah kepresidenan untuk mengelola masalah pendanaan teror. 


\section{INTRODUCTION}

The ability to effectively and efficiently collect, assess, disseminate intelligence information regarding threats posed by transnational and domestic terrorists on states securities estimated for the management of terrorist financing in Nigeria. The management of terrorist financing involves the ability to achieve control over the source, cash flows and their financial transactions. The management of terrorist financing by government also involves holistic strategy for detection and prevention of illegal business transactions including the establishment of policies and procedures that guide against money laundering and terrorist financing. Intelligence gathering is a tool that could be adopted in investigating terrorist's money transactions, financial ideology and utilization of their resources. Information gathering make use of Information Communication and Technology (ICT) mechanism to provide details on human activities and other resources, but the gap of intelligence gathering involves ethics and professionalism in outsourcing for information with adequate resources, knowledge and skills to discover every undiscovered facts, that is, intelligence acquisition needs professionalism (Leson 2005).

Hopwood (2012) described forensic accounting as an accounting specialization in which investigative and analytical skills are applied for the purpose of resolving financial issues in a manner that meets standards required by courts of law. Financial criminality is a state of violation of financial policies and standards and any form of irregularities or its equivalents in business and financial transactions, in that effect, terrorists financing is a form of financial criminality, terrorist financing requirements fall into two general areas: (1) funding specific terrorist operations, such as direct costs associated with specific operations and (2) broader organisational costs to develop and maintain an infrastructure of organisational support and to promote the ideology of a terrorist organisations. In the same line, forensic accounting techniques is suitable in the investigation of hiding financial operations and serves as internal control system to financial institutions and other financial agencies to enable intelligence gathering on the sources of funds available for terrorists. However, Chester (2008) emphasised that it is necessary and urgent to manage the financing system of terrorists and create awareness among financial institutions with the accessibility to communication and information on legality of business transactions, profiling and identifications of individual person that is involved.

Terrorism is a major threat to humanity and its society, the development of terrorism relies on religion than either political or cultural beliefs of the insurgents in Nigeria. No culture in Nigeria directly have trait of terrorist. The problem of terrorism increased due to the failure or irresponsibility of the governments to respond to geopolitical grievance, religious differences, and unstructured socio-economy which degenerates to the level of regional terrorism in Nigeria. The financing of terrorist cloud a surface leaving no directions, it appears as if the terrorists are from a different world, tracing terrorists and financing of terrorists became impossible mission. Investigation of terrorist financing requires personnel network (i.e. intelligence acquisition), antiterrorism networks and intelligence gathering system to trap and follow suspected individuals that are fundamentalist or an organization whose are involved in sponsoring terrorism. Lack of mechanism and procedure of intelligence acquisition and gathering disperses the management of terrorist financing and money laundering. This study insight on the usefulness of forensic accounting techniques on the management of terrorist financing using intelligence gathering as a tool to investigate and assist the military and other security forces to know how the source, pathway, destination and the utilization of the resources of terrorists. (FATF Report, 2012).

Intelligence gathering problem begins with the attitude, behaviour, culture, religion and acceptance of information from the people. Information is being compromised, manipulated and misused primarily from the sources and these affect the functionality of intelligence in gathering adequate information when necessary. In other words, lack of adequate security infrastructures and facilities also contribute to the failure of intelligence gathering in controlling terrorist financing in Nigeria. This study examine examine the relationship between forensic accounting and intelligence gathering on terrorist financing in Nigeria. 


\section{LITERATURE REVIEW AND HYPOTHESES DEVELOPMENT}

Williams (2012) stated that forensic accounting represents a certain type of professional expertise, which is supported by features that can be clearly identified as rationality, objectivity and independence. It was further stated that forensic accountants have particular social recognition, which is crucial to the economic issues and its translation into trust. Considering the variety of services provided by forensic accountants, different authors used a wide range of activities that forensic accountants conduct in order to examine the financial and non-financial information for the clarification of fraud, disputes and anticipated proceedings. Kahan, Manning and Wells (2010) stated that forensic accountants, by using financial information, can understand, interpret and distinguish the significant from insignificant, as well as reconstruct, identify, preserve, report and testify financial information obtained in the process of investigating fraud in court. Forensic accountants often analyse financial statements through various indicators such as: financial ratios, horizontal and vertical analysis of financial statements, data-mining techniques like Benford's Law and many others. Gray (2009) indicated that forensic accountants provide services in civil proceedings in respect of different situations, including: commercial procurement, valuation of marital property(s) in divorce proceedings, compensation claims, and lost profits due to tax fraud and money laundering. In general, forensic accounting can be divided into three broad areas: Investigative accounting, litigation service and computer forensic.

Lalit and Virender (2012) highlighted some of the techniques involved in forensic accounting to examine fraud, and some of these techniques were also applicable to track terrorism financing, they include; Benford's Law, Theory of Relative Size Factor (RSF),Computer Assisted Auditing Tools (CAATs), Data Mining Techniques (DMT) and Ratio Analysis (RA). Benford's Law: also called the First-Digit Law (FDL) is a phenomenological law about the frequency distribution of leading digits in many (but not all) real-life sets of numerical data. Theory of Relative Size Factor (RSF): It highlights all unusual fluctuations, which may be routed from fraud or genuine errors. Computer Assisted Auditing Tools (CAATs): Lalit and Virender (2012) described computer assisted audit techniques are the method of using a computer to assist the auditors in the performance of the computer audit. The major categories are audit software and test data. Data Mining Techniques: It is a set of assisted techniques designed to automatically mine large volumes of data for new, hidden or unexpected information or patterns (Lalit and Virender, 2012). Ratio Analysis: Ratio analysis involves calculating traditional and non-traditional financial ratios, such as accruals to assets, asset quality, asset turnover, days sales in receivables, deferred charges to assets, depreciation, gross margin, increase in intangibles, inventory growth, leverage, operating performance margin, per cent uncollectible, sales growth, and working capital turnover.

Nigeria Financial Intelligent Units (2013) explained that terrorists raise funds from diverse sources, move these funds through various medium and utilize the funds in different ways, in corresponding to Krieger and Meierrieks (2011) emphasized that terrorist groups acquire financial resources primarily from (i) state funding (ii) financing legitimate means (e.g. by legitimate business, charities, support diaspora etc.), and (iii) private financing by illegal means, usually including a full criminal activity (Transnational crime networks: Counterfeiting, drug trafficking, illegal logging, human trafficking, illegal mining, illegal fishing, illegal wildlife trade, crude oil theft, small arms $\&$ light weapons trafficking, organ trafficking and trafficking in cultural property). Perhaps, State-sponsored terrorism has declined in recent years, according to some experts, and is increasingly replaced by other types of backing. An individual with sufficient financial means may also provide substantial funding to terrorist groups. Late Osama bin Laden, for example, is thought to have contributed significant amounts of his personal fortune to the establishment and support of the Al-Qaeda terrorist network. However, the situation remain the same in Nigeria.

The gathering of intelligence to fill identified needs may require the deployment of 'human sources', such as informants or undercover officers, or the deployment of 
human or technical surveillance resources. At the higher level of operations there will be a requirements to access sophisticated covert entry techniques or intercept communications. Intelligence units at each levels in the model require access to these proactive resources to an extent that is appropriate to their business. Intrusive techniques are only available in serious crime cases and the requirements to protect the secrecy of methodologies makes it undesirable to use where they cannot be deployed securely. Mobile surveillance resources are generally expensive and requires a sound intelligence case to be made for their deployment. Intelligence is usually divided in two main areas are strategic intelligence and operational intelligence.: this intelligence typically provides an investigative team with hypotheses and inferences concerning specific elements of illegal operations of any sort. These will include hypotheses and inferences about specific criminal networks, individuals or groups involved in unlawful activities, discussing their methods, capabilities, vulnerabilities, limitations and intentions that could be used for effective law enforcement action. The components of intelligence gathering contains dissemination, tasking, collection, analysis, collation, evaluation, inference development to track the activities of terrorism and financing of terrorism. If these parameters were used appropriately, the effect on security intelligence will embrace adequacy, efficiency and effective of resources in combating the strategic and operation of terrorists'. (UN Report, 2011).

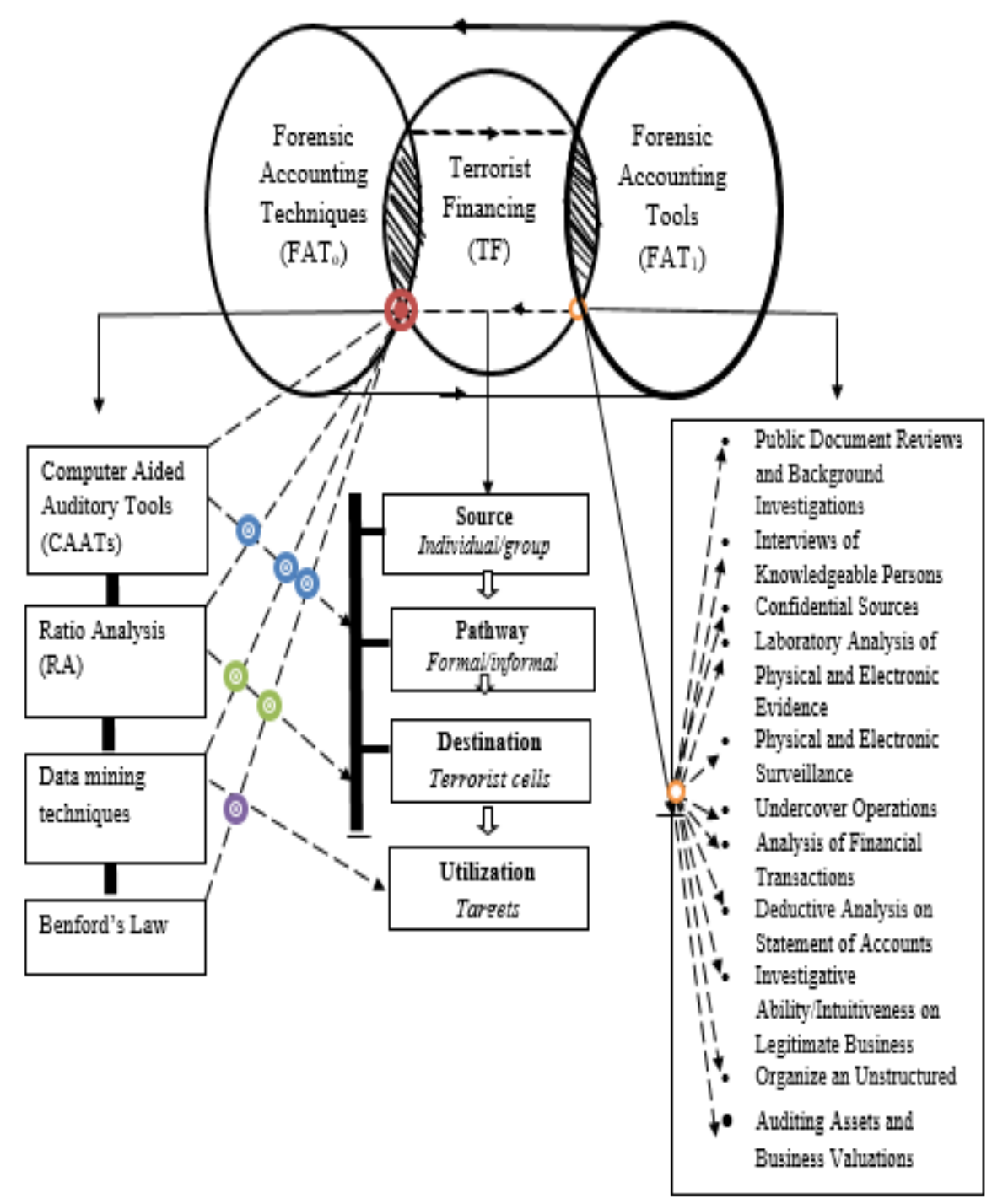

Figure 1. Conceptual framework on forensic accounting techniques $\&$ tools 
The following hypotheses were stated in null form as;

H1: Forensic accounting investigation and intelligence gathering have no significant effect on terrorist financing in Nigeria.

H2: Forensic accounting and intelligence gathering have no significant relationship in the investigation of terrorist financing in Nigeria.

\section{RESEARCH METHODOLOGY}

This study adopted secondary and primary sources of data collection and analysis. Secondary data were sourced from Nigeria Bureau of Statistics (NBS), Nigeria Financial Intelligence Units, Study of Terrorism and Responses to Terrorism (START), Financial Action Task Force (FATF), Global Terrorism Database (GTD) and Global Financial Integrity (GTI). Structured questionnaire was used to collect primary data. Econometric analysis (Factor Analysis with Monte Carlo Principal Component Analysis and correlation analysis) were used respectively at 5\% level of significant.

Model Specification

$\mathrm{V}_{\mathrm{t}}=\square \mathrm{V}_{\mathrm{f}}+\square \mathrm{V}_{\mathrm{i}}+\square \mathrm{V}\left(\mathrm{f}^{*} \mathrm{i}\right)+\square \mathrm{V}_{\mathrm{e}}$

Where:

$\boldsymbol{V}_{\boldsymbol{f}}=$ summation of the variability of forensic accounting techniques

$\boldsymbol{V}_{\boldsymbol{i}}=$ variability of intelligence gathering

$\boldsymbol{V}\left(f^{*} \boldsymbol{i}\right)=$ variability of interaction of forensic accounting with intelligence gathering

$\boldsymbol{V}_{\boldsymbol{e}}=$ error variability and

$\boldsymbol{t} \boldsymbol{f}=$ terrorist financing.

\section{FINDINGS AND DISCUSSION}

Factor analysis with Monte Carlo PCA and Pearson correlation were used as a stattistical tools to analysis the tested hypotheses. Factor analysis was used for the reduction and summarization of the data. The principal component analyses indicated that fifteen (15) forensic accounting techniques and tools were combined efficiently into four (4), explaining 94\% of the total variance among the inter-correlations of the fifteen (15) forensic accounting méthodologies in the analysis of N-59. The main four are: 1. Laboratory Analysis of Physical Electronic Evidence (LAPEE) 2. Analysis of Financial Transactions (AFT) 3. Deductive Analysis on Statement of Accounts (DASA) and 4. Data mining/ Big Data (DM/BD). The results spectacles that the sampling of the variables are adequate, since, the KMO value $=0.819>0.60$ of minimum constant value, therrfore, this indicated that the components of factor analysis are valid. The entire extracted variables are significant Graphically, the trends indicated the raise in the position of the component in dealing with terrorist financing. 
Table 1. Total Variance Explained

\begin{tabular}{|c|c|c|c|c|c|c|c|}
\hline \multirow[b]{2}{*}{ Component } & \multicolumn{3}{|c|}{$\begin{array}{c}\text { Total Variance Explained } \\
\text { Initial Eigenvalues }\end{array}$} & \multicolumn{3}{|c|}{$\begin{array}{c}\text { Extraction Sums of Squared } \\
\text { Loadings }\end{array}$} & \multirow{2}{*}{$\begin{array}{c}\text { Rotation } \\
\text { Sums of } \\
\text { Squared } \\
\text { Loadings } \\
\text { Total }\end{array}$} \\
\hline & Total & $\begin{array}{c}\text { \% of } \\
\text { Variance }\end{array}$ & $\underset{\%}{\text { Cumulative }}$ & Total & $\begin{array}{c}\% \text { of } \\
\text { Variance }\end{array}$ & $\begin{array}{c}\text { Cumulative } \\
\%\end{array}$ & \\
\hline 1 & 9.003 & 60.022 & 60.022 & 9.003 & 60.022 & 60.022 & 7.332 \\
\hline 2 & 3.369 & 22.461 & 82.483 & 3.369 & 22.461 & 82.483 & 6.495 \\
\hline 3 & 1.640 & 7.601 & 90.084 & 1.640 & 7601 & $0 \cap 084$ & 5.153 \\
\hline 4 & 1.378 & 4.522 & 94.606 & 1.378 & 4.522 & 94.606 & 4.621 \\
\hline 5 & 0.260 & 1.732 & 96.338 & & & & \\
\hline 6 & 0.178 & 1.185 & 97.524 & & & & \\
\hline 7 & 0.148 & 0.986 & 98.509 & & & & \\
\hline 8 & 0.097 & 0.645 & 99.155 & & & & \\
\hline 9 & 0.061 & 0.409 & 99.564 & & & & \\
\hline 10 & 0.028 & 0.187 & 99.751 & & & & \\
\hline 11 & 0.021 & 0.142 & 99.893 & & & & \\
\hline 12 & 0.012 & 0.077 & 99.970 & & & & \\
\hline 13 & 0.004 & 0.024 & 99.994 & & & & \\
\hline 14 & 0.001 & 0.005 & 99.999 & & & & \\
\hline 15 & 0.000 & 0.001 & 100.000 & & & & \\
\hline
\end{tabular}

Extraction Method: Principal Component Analysis 
Table 2. Monte Carlo Principal Components Analyses (PCA)

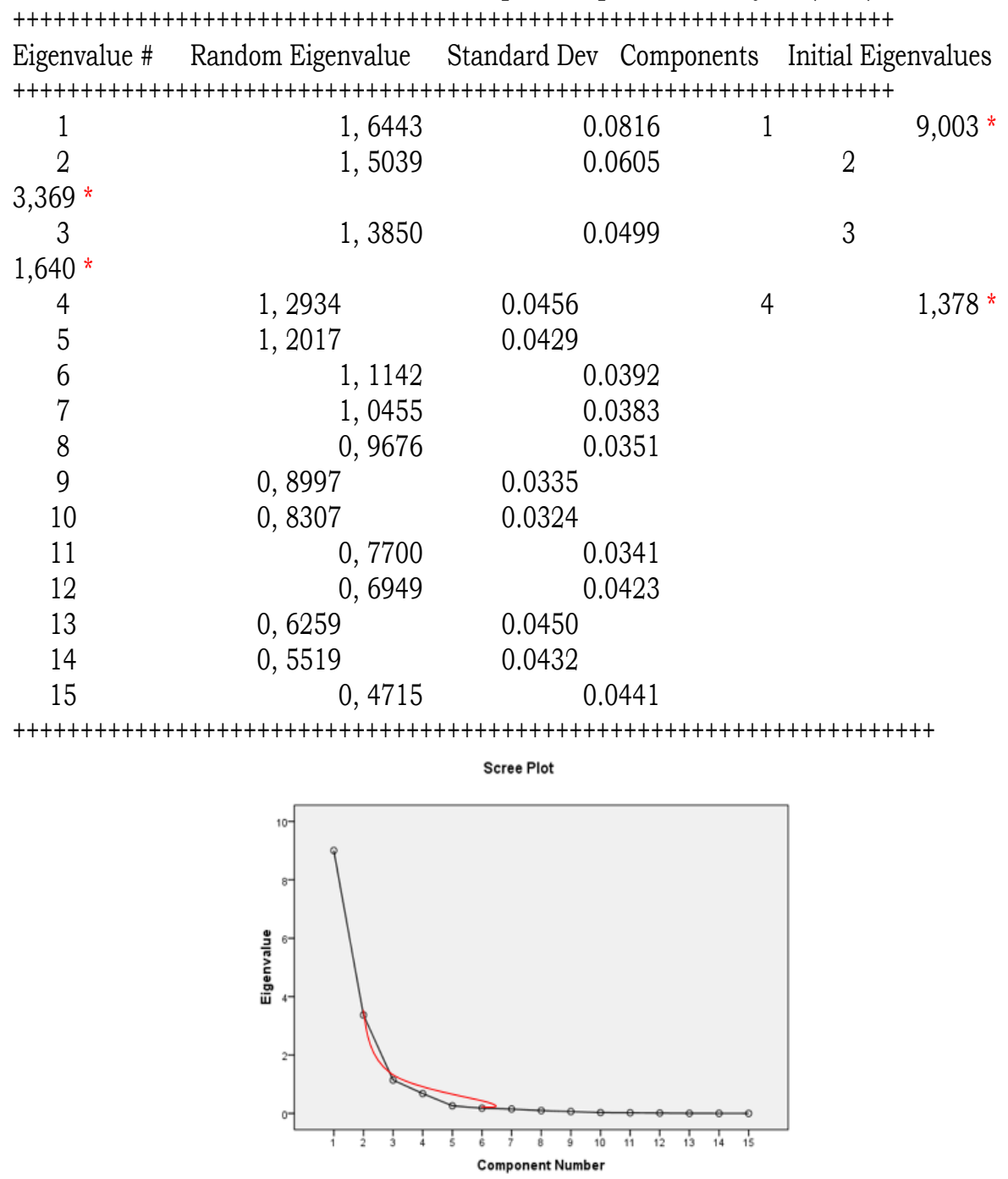

Figure 1. Trends TA and TR

The results of Pearson correlaton concluded that Laboratory Analysis of Physical Electronic Evidence (LAPEE), Analysis of Financial Transactions (AFT), Deductive Analysis on Statement of Accounts (DASA) and Data mining or Big Data (DM/BD) have positive correlation with Terrorist Financing. Correlation coefficients value $r=0.006$, $0.031,0.015,0.025,0.017,0.044,0.031,0.028,0.017$ and 0.000 revealed that forensic accounting practices have significant relationship with the investigation of terrorist financial transactions.

Table 3. Pearson Correlation Matrix

\begin{tabular}{|llllll|}
\hline Variables & TF & LAPEE & AFTs & DASA & DM \\
\hline TF & 1.000 & & & & \\
LAPEE & $0.006^{*}$ & 1.000 & & & \\
AFTs & $0.031^{*}$ & $0.017^{*}$ & 1.000 & & \\
DASA & $0.015^{*}$ & $0.044^{*}$ & $0.028^{*}$ & 1.000 & \\
DM & $0.025^{*}$ & $0.031^{*}$ & $0.017^{*}$ & $0.000^{*}$ & 1.000 \\
\hline
\end{tabular}




\section{CONCLUSION AND SUGGESTIONS}

The study concluded that intelligence gathering and forensic accounting methodology are suitable in disclosing and tracking the source of terrorists funding and their financial transactions. The results purview that the four (4) components (LAPEE, AFT, DASA and DM/BD) were retained based on the four Initial Eigenvalues that are greater than the Random Eigenvalue. i.e. $(1,6443<9,00301,5039<3,36901,3850$ $<1,64001,2934<1,3780)$. The results of Pearson correlation estimated that $r=0.006$, $0.031,0.015,0.025,0.017,0.044,0.031,0.028,0.017$ and 0.000 revealed that forensic accounting practices have significant relationship with the investigation of terrorist financial transactions. This research work recommended that Nigeria government should establish Response to Terrorism/ Terror Financing under the presidency to manage the problem of terror financing.

\section{REFERENCES}

Adegbie, F. F and Fakile A.S (2012). Economic and Financial Crime in Nigeria: Forensic Accounting as Antidote. British Journal of Arts and Social Sciences ISSN: 2046-9578, Vol. 6 No. 1

Adeleh, A. (2014). Analysis of the Necessity to Develop the Forensic Accounting in Iran. American-Eurasian Network for Scientific information (AENSI) 8(19) Special, Pages: 170-173

Chester, G. O. III. (2008) Terrorist, Insurgents, and Criminals--Growing Nexus. Journal: Studies in Conflict \& Terrorism Volume: 31 Issue: 1 Pages: 80 to 93

Dennis, L. (2002). Testimony of Dennis Lormel, Chief, Terrorist Financing Operations Section, Counterterrorism Division, FBI before the Senate Judiciary Committee, Subcommittee on Technology, Terrorism, and Government Information

Eke, C. C. (2013) Terrorism and the Dilemmas of Combating the Menace in Nigeria: International Journal of Humanities and Social Science Vol. 3 No. 4

Eli, B. L. and Iannaccone, R. (2006). The Good, The Bad, And The Deadly NBER Working Paper Series Religious Extremism: Working Paper 11663 National Bureau of Economic Research 1050 Massachusetts Avenue http://www.nber.org/papers/w11663

EMEH, Y. and OBI, J. O. (2013). An Empirical Analysis of Forensic Accounting and Financial Fraud in Nigeria. African Journal of Social Sciences, Volume 3 number 4, $112-121$

Enofe, P. O. Okpako E.N. Atube (2013). The Impact of Forensic Accounting on Fraud Detection. European Journal of Business and Management, Vol.5, No.26

Financial Action Task Force (FATF 2012). Financial Action Task Force on Money Laundering: Guidance for Financial Institutions in Detecting Terrorist Financing.

Financial Action Task Force (FATF 2013). Report Terrorist Financing In West Africa. http://www.giaba.org/media/f/632_TF-in-West-Africa.pdf

Gbegi, D. O and Adebisi, J. F. (2014). Forensic Accounting Skills and Techniques in Fraud Investigation in the Nigerian Public Sector. Mediterranean Journal of Social Sciences MCSER Publishing, Rome-Italy, Vol 5 No 3, E-ISSN 2039-2117

Gbegi, D.O Adebisi, J. F (2013).The New Fraud Diamond Model- How Can It Help Forensic Accountants in Fraud Investigation in Nigeria? European Journal of Accounting Auditing and Fiancé Research Vol.1, No. 4, pp.129-138 
Joel, L. (2005) Assessing and/ Managing the Terrorism Threat. Bureau of Justice Assistance

Joshua, M. (2014).Vulnerabilities and Responses to Terrorist Financing: An Exploration of Informal Value Transfer Systems (IVTS), Islamic Charities, And Businesses and Financiers. Internet Journal of Criminology 2014 ISSN 20456743

Kovalerchuk, E. V. and Robert H. (2011). Correlation of Complex Evidence in Forensic Accounting Using Data Mining.

Kranacher, (2010) Introduction to Fraud Examination and Financial Forensicshttp://media.johnwiley.com.au/product_data/excerpt/05/EHEPOO15/EHE P0015051.pf

Okoye, E.I \& Gbegi, D.O (2013). An Evaluation of Forensic Accountants to Planning Management Fraud Risk Detection Procedures. Global Journal of Management and Business Research Volume 13 Issue 1 Version 1.0

Zare, B. S. (2013) The Role and Necessities of Forensic Accountant in Accounting. Indian Streams Research Journal. ISSN 2230-7850, www.isrj.net 